\title{
ELISA LISPECTOR: A ESCOLHA DE UM ITINERÁRIO DESCONHECIDO
}

\section{ELISA LISPECTOR: THE CHOICE OF AN UNKNOWN ITINERARY}

\author{
Fernanda Cristina de Campos ${ }^{1}$
}

\begin{abstract}
Resumo: Este artigo pretende revisitar a trajetória literária de Elisa Lispector a partir de questionamentos existenciais impostos pelas protagonistas que compõem as várias narrativas dessa escritora. Tais questionamentos se entrelaçam na escritura como fios condutores, fazendo com que os estados emocionais das personagens se transfigurem ora na fluidez ora na fragmentação dos discursos, compondo, assim, a prosa poética. O resultado é uma escrita fragmentária e melancólica, permeada por imagens, símbolos e mitos que ganham destaque na estruturação e no conjunto da obra elisiana.
\end{abstract}

Palavras-chave: Elisa Lispector. Discurso. Melancolia. Imaginário. Imagens Poéticas.

Abstract: This paper aims to revisit the literary trajectory of Elisa Lispector from existential questions imposed by the protagonists who compose the various narratives of this writer. Such questions intertwine in the scripture as conducting threads, causing the emotional states of the characters to be transfigured, sometimes in fluidity, sometimes in the fragmentation of discourses, thus composing a poetic prose. The result is a fragmentary and melancholy writing, permeated by images, symbols and myths that gain prominence in the structure and in the Elisian work as a whole.

Keywords: Elisa Lispector. Discourse. Melancholy. Imagery. Poetic Imagery.

\section{Introdução.}

De todas as invenções de Dédalos, o labirinto parece ser a mais ousada e complexa. Arquitetura que foi projetada inicialmente para deter uma das mais temíveis criaturas da Mitologia Grega, o Minotauro, tornou-se, depois, imagem arquetípica que estimula o imaginário de diversos povos. Como observa Junito de Souza Brandão (2004), o labirinto tornou-se símbolo que se expande em sentidos e interpretações. Para o monstro, o labirinto,

\footnotetext{
${ }^{1}$ Doutora em Estudos Literários pela Universidade Federal de Uberlândia (UFU) e Mestre em Literatura Brasileira pela Universidade de Brasília (UnB). Como pesquisadora, integra o Grupo de Pesquisa CNPq POEIMA - Grupo de Pesquisa Poéticas e Imaginário. Como professora de Língua Materna, atua na Rede de Ensino Colégio Batista Mineiro e na Escola Pública do Estado de Minas Gerais.
} 
designava prisão, porém, para o povo de Creta, personificava-se em livramento, fazendo dessa estrutura um símbolo arquetipal que une a razão pragmática associada ao desvario.

E ao longo do tempo, a imagem do labirinto foi sendo tomada como prova iniciática que acena à peregrinação e à busca incessante de liberdade. Vale ressaltar que a maioria dos rituais possui cenas ou passagens cheias de meandros que conduzem o iniciado a vias tortuosas, incertas, misteriosas e cheias de espanto, denotando o teste de resistência por meio da lógica desordenada.

Nesse sentido, associamos, neste trabalho ${ }^{2}$, a imagem do labirinto à árdua trajetória literária de Elisa Lispector que, desde a sua estreia no campo das letras, revelou-se detentora de um substancial exercício com a linguagem, capaz de mover o leitor ao encontro com uma narrativa singular e imaginativa. Sua escrita revela uma busca de autoconhecimento pautada na expressão poética tecida por imagens que transcendem o prosaico e o registro realista.

Por meio de sua narrativa, em especial, pelo trabalho com a linguagem poética, deparamo-nos com a persistência de Elisa de se autofirmar como escritora em um contexto que teimava em negar o direito à mulher de ser escritora. Daí a imagem arquetipal de uma escrita tecida nos meandros de uma existência solidificada em inúmeros itinerários que solidificavam a sensação de nunca chegar ao destino pré-estabelecido pelo desejo.

Sua produção literária fundamenta-se na reflexão sobre conflitos existenciais, revelando o compromisso com um estilo consciente de sua poeticidade ao tematizar os mais recorrentes e, ao mesmo tempo, incompreensíveis sentimentos como a solidão, o amor, a morte, o desespero. Tais sensações povoam contextos por onde o imanente, representado por dilemas e frustrações do cotidiano, toca o transcendente desejo de morte. Na tensão que surge entre os deslocamentos que parecem não alcançar um fim, formam-se imagens que se fundam em percursos labirínticos geradas pelo estado agônico e melancólico de cada personagem elisiana.

A autora escreve no pós-guerra, momento em que as civilizações sofreram com as grandes transformações sociais, políticas e econômicas. Tempo marcado por questionamentos profundos que resultaram na intensificação de crises psíquicas como as grandes depressões. Isso contribuiu para a criação de imagens densas que denotam angústias intermináveis. Suas personagens, na maioria mulheres, ancoram-se em reminiscências estilhaçadas, lançando-se ao

\footnotetext{
${ }^{2}$ Este artigo é uma releitura de minha dissertação de mestrado intitulada $O$ discurso melancólico em Corpo a corpo, de Elisa Lispector, defendida em junho de 2006 pela Universidade de Brasília - UnB.
} 
mundo como testemunhas em plena desorientação, numa sociedade confusa, desordenada e muito propensa a temíveis perversidades.

Evidenciam-se, em cada itinerário narrativo, marcas estilísticas de uma escrita moderna que tenta se impor diante do caos a fim de convertê-lo em contextos mais amenos. Elisa Lispector expressa via escritura o fracasso e a queda de seres desesperançados que ainda se aplicam a certas reabilitações. Suas personagens deparam-se com a exígua solidariedade humana contida no egoísmo exacerbado, no tédio e na perplexidade diante da finitude. Por isso, a morte é almejada como saída desses estágios infernais e labirínticos.

Os questionamentos e as reflexões contidos no conjunto dessa obra pouco estudada, chamaram-nos a atenção. O vazio existencial que caracteriza cada personagem elisiana é a causa da incredulidade incomensurável na vida, corroborando para a construção de um discurso melancólico, fruto de estados doentios que retratam o homem moderno.

\section{Melancolia, solidão e dor: vias labirínticas que marcam uma travessia poético- existencial}

Os livros de Elisa Lispector abrem espaços para reflexões filosóficas, como a ininterrupta angústia existencial frente aos prementes conflitos entre vida e morte. A morte não é vista como fim, mas como caminho para de libertação e fuga da realidade. Em cada narrativa há por parte das personagens um mergulho em si, numa profunda introspecção que é a busca constante de autoconhecimento que não contribui para uma cura, mas sim para um estado letárgico e melancólico. São indivíduos impelidos a um certo isolamento geográfico que antecede a constantes mobilidades, fazendo refletir as perturbações psíquicas enfrentadas por cada personagem. Daí a dialética do deslocamento e da prisão presente constantemente nos enredos.

Desse isolamento resulta o avultamento do tema solidão, sentimento imprescindível que acompanha a maioria das personagens elisianas, em especial, as femininas. Pela análise de seus múltiplos desdobramentos, vem à tona uma possível ponte biográfica para explicar o interesse pela temática: o problema da identidade vivido por Elisa Lispector, imigrante e judia, que chega ao Brasil nas primeiras décadas do século XX. Possivelmente, em Elisa Lispector, é dessa solidão de "não pertencer" que nascem a angústia e a melancolia, como temas centrais. 
Há na obra elisiana várias marcas que denunciam as dores de um êxodo sofrido ainda na infância, provocadas pelo périplo vivido pela família Lispector. No livro Clarice uma vida que se conto (2009) em especial, no capítulo, "Da Rússia a Maceió e Recife”, de Nádia Battella Gotlib, são descritos os principais desdobramentos desses intensos deslocamentos. Quando Elisa Lispector era ainda uma garotinha, seus pais, fugindo do antissemitismo da Primeira Guerra Mundial, deixaram a Ucrânia, terra natal, em 1920, e vieram para o Brasil, radicandose no Nordeste. A partir de então, a família composta por pai e mãe (Marietta e Pedro Lispector) e três filhas (Elisa Tania e Clarice Lispector), sendo Elisa a filha mais velha, passa a residir em Maceió (1920) e mais tarde em Recife (1925).

Após morar muitos anos em Pernambuco, Elisa muda-se para o Rio de Janeiro, em busca de oportunidades de estudo e trabalho. No Rio, por meio de concurso, ingressa no Serviço Público Federal. Dentre as funções importantes que desempenhou no Serviço Público, Elisa Lispector teve incumbências no exterior ao fazer parte de delegações governamentais. Ministrou duas importantes conferências internacionais sobre assuntos trabalhistas em Genebra. E sobre previdência social fez palestras em Buenos Aires e Madri, procurando destacar os problemas da mão-de-obra feminina na América Latina.

É também na capital carioca que Elisa Lispector faz os seus primeiros contatos literários, passando a colaborar com várias revistas e jornais. O ano de 1945 foi um marco para a autora ao ter o seu primeiro romance, Além da fronteira, publicado. Com este romance, Elisa Lispector inicia uma intensa dedicação ao universo das Letras.

Os seus trabalhos estão voltados, sobretudo, às temáticas intimistas que cercam o homem moderno, tendo como singular propósito desvelar os conflitos que giram em torno dos porquês sobre o ser no mundo. Sua narrativa traz como marca invulgar um enredo que tende a perder os contornos e as divisões nítidas até se desfazer no fluxo da memória, evocando um sentido estritamente poético, o qual se afasta cada vez mais do conceito trivial de realidade.

Para evocar essas questões referentes à crise existencial, Elisa Lispector não recorreu unicamente ao monólogo interior, mas trabalhou com outros recursos narrativos tradicionais como o diálogo e o relato irônico, usando preferencialmente o discurso em terceira pessoa. $\mathrm{O}$ resultado foi uma prosa elegante com marcas de uma tessitura tradicional que oscila com aspectos modernos da narrativa.

Já na primeira publicação, vemos a negação à função documental da prosa romanesca caracterizada por uma dicção narrativa feita de rupturas e de desintegração da linguagem. Elisa 
não foi tão radical como sua irmã Clarice Lispector que trabalhou com uma escrita altamente complexa e abstrata em seus contos e romances. Elisa preservou um certo preciosismo na forma de articular as palavras, mas nem por isso perdeu a singularidade de seu trabalho com linguagem.

Estamos diante de uma literatura questionadora e sensível, cujo foco se detém sobre problemas da esfera do $e u$ - personagem-ego. Além disso, há na prosa elisiana uma intimidade ligada a uma nova forma de trabalhar com a linguagem. Trata-se de um retraimento que conduz à vida particular de homens e de mulheres comuns que lutam e clamam por uma felicidade impossível de ser alcançada neste mundo conturbado e desordenado.

Não se trata de uma narrativa voltada à propagação de valores moralistas, herança de pensamentos conservadores disfarçados que privilegia o culto das virtudes. Pelo contrário, é uma linguagem reveladora de impasses e de inseguranças que coloca em cheque indivíduos sem esperança diante de perdas, exílios e depressões. A autora não demonstra pudor ou receio ao arquitetar sua arte poética que desnuda pensamentos e pulsões advindas de almas perturbadas.

Dessa forma, a pergunta incansavelmente feita nos textos elisianos é: "qual o sentido da vida humana neste específico tempo histórico em que vivemos?” (UP, p.127) ${ }^{3}$. Por isso, como afirma o crítico Walmir Ayala, a narrativa elisiana se faz palco "de um certo lirismo que em prosa objetiva a introspecção e compõe um painel heterogêneo no qual a história é mais uma atmosfera do que um incidente". (AYALA, 1963).

Ao tecer suas narrativas, Elisa Lispector foge de emblemas neoconservadores impostos à condição feminina ainda bem evidentes no contexto sociopolítico brasileiro da década de sessenta e setenta. Em quase todas as esferas da sociedade brasileira, o pensamento que imperava acerca do papel da mulher se resumia no compromisso com o casamento e com a maternidade. E qualquer narrativa que negava tais conjunturas era considerada como ameaça às expectativas impostas ao universo feminino. Todavia, Elisa Lispector não se intimidou diante de julgamentos e críticas ao transferir para sua narrativa conflitos que colocavam em cheque

\footnotetext{
${ }^{3}$ Ao longo do artigo, utilizaremos, nas citações, as seguintes siglas das obras, de Elisa Lispector: Além da fronteira (1945) AF; No exílio (1948) NE; Muro de pedras (1963) MP; Dia mais longo de Thereza (1965) DMT; A última porta (1975) UP; Corpo a corpo (1983) CAC.
} 
condutas paternalistas. Suas temáticas tendem a outras discussões ligadas à estética, à filosofia e à psicologia existencial.

Os enredos imaginados revelam inquietações que rondam a mente humana continuamente como o medo diante da finitude da vida, a angústia e a incomunicabilidade imposta pelos fenômenos da modernidade como guerras e exílios. As interrogações que se colocam visam atingir o leitor por meio de recursos renovados da prosa poética, fazendo-o a refletir sobre a condição humana diante de sentimentos como a solidão cada vez mais presente no contexto de vida moderna.

Nesse desentranhar de tensões, consolida-se um modo especial de fazer literatura, o qual se deu por meio de um exercício contínuo com a linguagem, tendo como base um lirismo que se transfigurou em

fatos em função de uma energia emocional. Dentro do jogo claro de uma vida ela traça toda uma formulação criadora. Esta formulação expressa em parágrafos quase técnicos deixa claro o rumo da seleção de elementos aparentemente e insignificantes, da dúvida diante do que terá realmente importância, do aprofundamento na marginalidade (AYALA, 1963).

Como que fisgados por essa energia emocional que se transfigura em prosa poética, passamos, ao itinerário sobre o conjunto da obra literária de Elisa Lispector. Como foi mencionado anteriormente, Elisa publica seu primeiro livro, o romance Além da fronteira, em meados da década de 40. Este livro conta a triste e comovente história de um jovem escritor, Sérgio, vitimado por vários fracassos, principalmente como escritor. O protagonista não teve a sorte de possuir uma família sólida, nem ao menos de conhecer os pais, sendo obrigado a viver em companhia dos tios, Ernesto e Nelly - pessoas rígidas que "conservavam sempre os mesmos hábitos, entregavam-se metodicamente às mesmas tarefas. Eram pessoas sem idade, sem ternura nem alegria" (AF, p.25).

Ainda na adolescência, Sérgio é fascinado pela escrita e, então, opta pela carreira intelectual - quis ser escritor: "tinha necessidade de criar obra sua, precisava encontrar o seu próprio meio de expressão" (AF, p.5). Porém, depara-se com o fracasso profissional, por não conseguir publicar muitos de seus livros. Seus romances, como afirma o personagem Sr. Rodrigues - dono de uma editora -, não chamavam a atenção de leitores menos intelectualizados. Com uma linguagem altamente subjetiva, Sérgio delineava suas personagens 
complexas que subvertiam a realidade. Tais características literárias não produziam interesse nos leitores e, por isso, seus livros eram renegados, pois não proporcionavam lucro às editoras.

Elisa Lispector, com este romance, evoca um problema, ou melhor, um mal-estar ainda recorrente no campo literário, ocasionado pela invasão mercadológica que tem transformado o livro em artigo de luxo ou mercadoria supérflua. Com mais intensidade, vemos, a partir da década de 50 (exatamente quando a autora inicia sua carreira intelectual), as publicações terem como alvo as massas - leitores em maior quantidade, porém menos exigentes e intelectualizados:

As suas novelas são por demais subjetivas, e as suas personagens (...) estão situadas fora da realidade. Os leitores de nível comum não as compreendem. Elas lhes turbam a paz. O público que lê procura nos livros um pouco de amenidade, o calor da simpatia, da compreensão, um tanto de fantasia também, convenho, mas nada dos conflitos acerbos que se situam nos seus relatos (AF, p.7).

Sérgio sente-se encurralado nesse mundo movido pelo lucro, onde tudo se transforma em mercadoria, até mesmo a arte poética. Isso provoca no escritor-personagem um estado profundo de melancolia, principalmente, quando se vê obrigado a curvar-se "em face das leis do mercado, errante em meio a coisas ruinosas e fragmentos de um universo esfacelado e carente de uma harmonia já consumada”. (ARRIGUCCI, 1990, p. 272).

Sérgio é descendente de judeus, identidade revelada de forma implícita pelo narrador em terceira pessoa. Sua obra é fruto de experiências de guerra e de sofrimentos causados por exílios forçados e expressa a aterradora angústia existencial de uma época caótica. Sentimentos que justificavam a razão impeditiva para o sucesso de seus livros. Para Sérgio era impossível negar o passado, a história, a subjetividade a fim de atender as expectativas do mercado financeiro:

\footnotetext{
Um dia somos concebidos casual ou propositadamente e dão-nos à luz, e moldam-nos os sentimentos e a inteligência, quando não nos abandonam aos caprichos da sorte, até o dia que nos fazemos conscientes. Então uma vontade em nós se revela, mas quase inevitavelmente entramos em choque com as circunstâncias que nos rodeiam. (...) Enquanto a morte não vem, a vida passa vazia, efêmera e inglória (AF, p.18).
}

A morte para o protagonista transforma-se em solução possível e caminho de salvação diante de uma vida triste e inócua. Por meio dessa personagem, Elisa Lispector reflete sobre o artista contemporâneo, que se vê como um indivíduo irrealizado, em desassossego dentro de 
um universo social caótico, incapaz de arquitetar objetivos e vislumbrar perspectivas. Com este romance, tem-se o retrato do artista pintado como um peregrino errante em sua própria pátria, procurando entender o mundo pelo viés da escrita, na busca de firmar uma aliança consigo mesmo e com a terra. Sérgio é o indivíduo que vive sob o regime do limite e habita um entrelugar, almejando uma abertura em um mundo invisível para apreender o sentido de uma fronteira que separa o tudo e o nada, o ser e o não-ser, o efêmero e a eternidade.

É notável quanto o tema da morte ganha contorno e importância dentro da obra de Elisa Lispector, ao lado de outros assuntos relevantes como a solidão, a crise existencial e a melancolia. Esses temas nos são apresentados a partir dos deslocamentos realizados pelas personagens, seguidos de profundo desamparo e isolamento. Nos enredos apresentados - e em outros que se seguirão - observamos uma necessidade premente desses indivíduos de se deslocarem. Talvez, esse procedimento se justifique pela ânsia das personagens em buscar soluções e cura para as rejeições e os abandonos que sofreram.

Em Clarice Lispector essa característica também é apontada por Gilberto Figueiredo Martins: "a mobilidade marcaria também seus textos como motivo temático e processo compositivo: os deslocamentos geográficos multiplicam-se em sua história e nas estórias que conta”. (MARTINS, 2002, p. 5).

Possivelmente, esse modo de narrar das irmãs seja proveniente do arquétipo nômade, fruto de um patrimônio proveniente de berço judaico. Elisa Lispector, ao contrário de Clarice, fez questão de enfatizar, via escritura, as marcas de sua identidade e cultura judaica. Por isso, seus livros são tidos como acervos preciosos para a comunidade judaica no Brasil. Verificamos essa "presença" com mais força em seu livro No exílio - segundo livro publicado com nuances autobiográficas.

No exílio narra o triste destino de uma família forçada pela guerra a fugir de seu país. Obrigada a buscar enraizamento em uma terra distante e diferente, a família retratada vive dias de solidão, angústia, medo e muita violência. A autora sintetiza com precisão "os confrontos seculares do nomadismo, a vivência contínua de migrações, cortes e renúncias” (MARTINS, 2002, p. 5) que marcaram a história de um povo incompreendido e perseguido desde tempos remotos.

Nesse romance de fundo autobiográfico, Elisa Lispector descortina as perseguições e os grandes conflitos vividos pelos judeus, seus esforços em radicar-se em novos países, a luta pela Terra Prometida, Israel, e apresentando a dimensão subjetiva do desenraizamento e do exílio. 
A autora tematiza nesta obra os efeitos da situação quando se é forçado a sair da terra, deixando para trás a língua, a cultura, os bens, os parentes, os amigos, as crenças religiosas e outras referências, para começar, do nada, uma nova (sobre)vida em um outro país, tendo que se habituar a novos costumes e cultura - inclusive aprender uma nova língua.

Narrado em terceira pessoa, No exílio tem como protagonista Lizza, filha mais velha de uma família judia que vem para o Brasil com o objetivo de amenizar as dores decorrentes das terríveis perdas provocadas pela Primeira e Segunda Guerra Mundial e pela tentativa de extermínio da raça judia. A história se inicia com a saída da personagem do sanatório, depois de se restabelecer de uma estranha enfermidade, ao que parece, uma intensa crise melancólica seguida de debilidade psíquica e física. Com a saúde mais estável, Lizza, busca na memória o passado recente e o revive, com o intuito de analisar os dias de infindável agonia e sofrimento, resultado do êxodo forçado.

A maioria das personagens elisianas recorre à memória como instrumento singular na tentativa de se reencontrar como sujeitos de suas histórias. Segundo a estudiosa das tradições judaicas, Berta Waldman, "a memória do passado foi sempre um componente central na experiência judaica, e a referência à memória coletiva não é uma metáfora, mas uma realidade social transmitida e sustentada através de esforços conscientes" (WALDMAN, s/d, p. 21). A importância dada pelos judeus ao passado, recuperado via memória, é um resquício cultural encontrado na narrativa elisiana: "graças à memória que o passado flutuante pede passagem e se deposita de diferentes modos no texto literário." (WALDMAN, s/d, p. 21).

Assim, por meio de uma narrativa marcada por digressões, o narrador onisciente perscruta os pensamentos de Lizza e relata as mais pavorosas noites, "semeadas de espectros e de terror" (NE, p.8), vivenciadas pela protagonista e seus parentes ao tentarem emigrar para o Brasil, fugindo dos pogroms - as terríveis e violentas perseguições aos judeus promovidas pelo exército "branco". Estes eram comandados por alemães, que invadiram parte da antiga União Soviética, destruindo tudo o que encontravam pela frente, dizimando inúmeras famílias. Esses soldados estupravam mulheres, matavam e saqueavam multidões; houve, inclusive, o extermínio de cidades inteiras.

Todo o percurso da viagem é narrado, culminando com a dificuldade da família em estabelecer residência em uma nova terra - um outro terrível problema enfrentado pelos expatriados. Verificam-se ainda menções de fatos históricos misturados às ações fictícias, com um meticuloso painel histórico-documental permeando o projeto estético da autora. 
O narrador, ao contar a história de Lizza, cita alguns exemplos das funestas condições de vários países do leste europeu, depois de ser instaurada a Primeira Guerra Mundial, revelando os resultantes conflitos psicológicos das personagens:

1917. Fadiga. Exaustão. Campos abandonados. Estradas obstruídas. Quebranto de forças e esperanças sumidas. E por toda parte uma dolorosa fome de pão e de sossego - pão, para saciar as ânsias do corpo, sossego e esquecimento para apagar as amarguras da alma. A guerra, no entanto, continuava a devorar homens. Essa guerra, que os arrancava brutalmente dos campos e lares, já se estava tornando assaz cruenta, demasiado voraz.

Judeus continuavam encerrados nos campos de concentração, agora policiados por soldados aliados, e as portas da Palestina permaneciam seladas pelo Livro Branco. (...) Da Alemanha nazista, os judeus continuavam esquecidos. Os clamores de seu sangue inocente, sacrificados nas câmaras de tortura e morte, como o derramado com heroísmo nos campos de batalha, permaneceram sem repercussão.

Como todo homem de pensamento, ele [Pinkas] acompanhava com apreensão a marcha dos acontecimentos. Presenciou a visita de Chamberlain a Hitler. Deramse as mãos, cumprimentaram-se afavelmente. Depois Chamberlain voltou para o lugar de onde tinha vindo, e Hitler prosseguiu na sua faina genocida (NE, p. $29 ; 157 ; 183)$.

A autora faz um registro da história do exílio judaico pelo viés pessoal e memorialístico de uma personagem judia, que se coloca numa posição duplamente marginal: como uma mulher que conhece e sofre agressões das forças de repressão do poder falocêntrico e como uma imigrante posta à margem de uma sociedade patriarcal e estranha. Expondo as condições marginais da protagonista, Elisa cria situações denunciadoras tanto da condição inferior da mulher imigrante quanto dos problemas sociais, econômicos e psicológicos sofridos pelos exilados:

Poucas eram as famílias que os visitavam, porque Marim [mãe de Lizza] era doente, e a casa triste pouco convidativa para estranhos. De longe em longe, levava a filha mais velha ao clube israelita. A mãe dizia que era preciso ir, que não se importassem com ela. Lizza ia. Mas era como sair de um barco e jogar-se ao mar. Sentia-se deslocada naquele meio onde não conhecia ninguém e era diferente de todos, parecia-lhe. O pai a recriminava, falava acerba e tristemente. - Aquilo era portar-se como selvagem. Quando chegaria a ser gente? Ela ouvia e calava. Sofria mais pelo desgosto que dava ao pai, do que, mesmo, pelo próprio desapontamento. Em casa, encontrava a mãe chorando (...) Lizza roía-se de remorsos, prometendo a si mesma não mais sair, não mais deixar a mãe naquele estado (NE, p.111). 
A própria autora conheceu profundamente a tristeza e a dor do exílio, quando sua família, fugindo das consequências deploráveis da guerra e da violência dos pogroms, mudouse para o Brasil. Tanto as personagens como alguns lugares citados no enredo do livro em questão remetem à própria vida de Elisa Lispector ${ }^{4}$. Essa realidade autobiográfica reforça a grandeza do testemunho trazido por esse romance, pondo em destaque os "problemas individuais e [o] drama coletivo de um povo, de toda uma época, caracterizada por grandes violências contra o ser humano". (JOSEF, 2005).

Em 1962, Muro de pedras é publicado e com esta narrativa Elisa Lispector é a primeira escritora a receber o prêmio José Lins do Rego concedido pela Editora José Olympio. Como discussão central, este romance traz a problemática da mulher, associada a reflexões sobre a finitude humana. Narrado em terceira pessoa, conta a história de Marta, uma mulher que se vê perdida ao constatar a impossibilidade de "estabelecer a paz consigo mesma" (MP, p.12), por se sentir desde criança, um ser abandonado, à margem da vida. Trata-se do anseio e, ao mesmo tempo, dos inúmeros obstáculos enfrentados por alguém que pretende se afirmar como sujeito de sua própria história.

Com essa obra, Elisa empreende uma narrativa que expõe conflitos internos resultantes dos choques social e emocional sofridos pela protagonista numa sociedade patriarcal, proporcionando uma reflexão sobre a condição feminina na década de 60. Há uma nítida preocupação da autora em situar e representar, por meio de temas e certas perspectivas da realidade, a mulher como sujeito (ou, pelo menos, na tentativa de ser sujeito) de sua própria história em que o egoísmo falocêntrico e a dominação masculina sempre escravizaram e anularam a feminilidade, transformando as mulheres objeto de outras histórias.

Comumente às personagens elisianas, Marta fracassa na tentativa de se impor como sujeito e entra em choque com a ideologia imposta pela sociedade. A protagonista de Muro de pedras, não obstante, subverte algumas regras da sociedade vigente, vendo-se livre de alguns ritos e instituições tradicionais, como o casamento. Suas ações, porém, subversivas não garantem a verdadeira liberdade, transformando Marta em um ser desorientado e incompleto.

\footnotetext{
${ }^{4}$ Vale ressaltar a semelhança do nome Lizza com o nome da própria Elisa. Essa semelhança é notável também em relação aos nomes das outras personagens do romance com os nomes dos familiares da autora: Marietta e Pedro Lispector, e as filhas Elisa, Tânia e Clarice. Além disso, a família da personagem, assim como a família Lispector, é composta pelo pai, Phinkas, a mãe, Marim - esta como a mãe de Elisa morre logo depois de chegar ao Brasil e as três irmãs, Lizza, Ethel e Nina, o que torna mais evidente o tom autobiográfico do romance.
} 
Filha única de um casal de classe média, tivera uma infância marcada pelo desprezo e ausência dos pais. O pai foi uma figura ausente física e emocionalmente, pois, durante toda a infância da filha, esteve acamado em um sanatório tentando se recuperar de uma doença não mencionada. A mãe, Eunice, sempre muito ocupada com seus afazeres, não dispunha de tempo para dar atenção à única filha. Assim, a insegurança e a solidão compunham o cotidiano de Marta.

Na busca de superação contra as frustrações familiares, a protagonista investe em vários relacionamentos amorosos. Primeiro, casa-se com Heitor, porém a passividade e a falta de amor deste para com ela colaboram para o fracasso do casamento. Sem antes recuperar-se dos traumas proporcionados pelos dias vividos com Heitor, a protagonista envolve-se com Maurício, um rapaz bem mais jovem que ela. Este, para não pôr em risco a reputação de garoto em plena virilidade, mantém em segredo o relacionamento com Marta, pois a considerava uma mulher "velha" demais. Além disso não enxergar nela beleza alguma. Marta ao perceber os verdadeiros sentimentos de Maurício, põe fim ao caso.

E, após tantos fracassos amorosos, ela sente-se "emparedada dentro do seu sofrimento como um morto dentro de seu túmulo" (MP, p.39). Não havia ninguém em quem pudesse se apoiar. Sabia que era preciso recomeçar, aprender a viver novamente, mas como? - perguntavase desesperada, antevendo o seu terrível destino.

Fatigada pela hipocrisia dos relacionamentos da cidade, Marta busca refúgio exilandose numa antiga chácara deixada de herança pelo pai. Imaginava que o contato com a natureza pura e calma do campo poderia proporcionar-lhe um sentido maior para a existência. Impunhalhe um deslocamento tal qual um exílio.

Em seu texto "Escrever estrelas (ora, direis)", Clarisse Fukelman afirma que a vontade muitas vezes incontrolável do homem moderno de se isolar vem da sua necessidade de refletir sobre a própria condição, "agravada por um tipo de organização social que segrega os indivíduos entre si”. (FUKELMAN, 1997, p. 9). Assim, a personagens criada vê-se num desterro de sua própria terra em busca de respostas na tentativa de compreender o sentido da vida. Essa inquietação pode ser própria do artista a buscar, por meio da escrita, a "sua própria identidade e a sua própria humanidade, cara a cara com as de uma outra pessoa" (FUKELMAN, 1997, p. 9) - no caso, suas criações.

Como última cartada em busca de felicidade, Marta cede à maternidade na tentativa de preencher o vazio existente em seu íntimo. Neste intento, entrega-se a Bruno, o rústico 
administrador da granja, e fica grávida. Dá à luz um menino e, então, compreende que a solidão não lhe era mais necessária. Com o menino no colo, a personagem tinha a sensação de possuir o “próprio mundo, o seu mundo, a sua vida nas próprias mãos” (MP, p.138).

Com o transcorrer do tempo, ao ver o menino crescendo e ficando cada vez mais independente de seus cuidados maternos, Marta se vê relegada novamente à inutilidade dos dias. Fatigada pela mesmice e lassidão do sítio, começa a sentir-se melancólica e depara-se novamente com a angústia de viver. Não compreende o tormento da eterna insatisfação: "na cidade quisera a quietude do campo; no campo - o que era mesmo que desejava agora?” (MP, p.143).

Por fim, percebe ser falsa a sensação de paz proporcionada pela maternidade que, por pouco tempo, experimentou em seu ser. Parece que a verdadeira quietude ou tranquilidade interior jamais seria alcançada.

Marta se regozijava e entristecia um pouco. Seu filho estava crescendo, cada vez mais absorvido pela beleza do mundo, pela grandeza do mundo. Sobretudo isto: sabia que entre ela e o filho existia uma barreira intransponível, pois compreendia que as criaturas deixam de aterrorizar-se diante do desconhecido no dia que perdem a infância, esquecem o mistério que se prolonga para além do meramente sensorial, perdendo a capacidade de maravilhar-se diante do encantamento dos sonhos (MP, p.148 e 149).

Novamente o mito do amor materno é posto em questão. Primeiro pela mãe de Marta quando a menosprezava, tratando-a com frieza e ironia. Depois pela própria protagonista que não consegue demonstrar ao filho carinho de mãe. O mito do amor materno é subvertido como também o pensamento que afirma que para a mulher sentir-se completa e totalmente realizada precisa gozar do ato pleno que é o de ser mãe.

Outro livro que questiona os modelos patriarcais que ditam regras sobre a essência feminina é $O$ dia mais longo de Thereza. Este é estruturado numa narrativa linear com uma linguagem objetiva que deflagra aspectos profundos acerca da solidão inerente ao ser humano. Este livro conta a história de uma mulher muito parecida com Marta, a qual se encontra afundada num imenso poço de angústia existencial. Porém, com mais intensidade que a protagonista de Muro de pedras, Thereza possui uma fixação, ou melhor, uma obsessão doentia pela morte. Assim como o protagonista de Além da fronteira, ela concebe a morte como libertação e não como a extinção de seu ser. 
Para a personagem, a imagem de morte não se liga a sentimentos negativos, como uma força devastadora ou incompreensível. Ao contrário, Thereza vê na morte uma saída, a solução para sua vida inóspita e sem sentido. Ela enxerga o fim como uma sina, fenômeno iniludível na vida de qualquer ser humano:

E de repente, pareceu-lhe que toda a sua vida tinha sido uma caminhada inútil, de passos perdidos, a não ser no que a conduzia à morte, - "muito mais caudalosa do que a vida, e mais grave também", obtemperou, não sem um acento meio zombeteiro, como quem quisesse desconversar (DMT, p.11).

Thereza lida o tempo todo com a angústia pelos dias vividos e com um incomensurável cansaço de viver. Ela se exaspera diante dos fracassos cotidianos (alguns muito simples, outros irremediáveis) e também sofre com a incomunicabilidade sentimental, que faz dela um ser fatigado, fragmentado e totalmente solitário. Ao perceber em situação conflitante, não hesita em pensar na morte como a mais sensata escolha para o fim de tanto sofrimento, uma vez que convivia com uma intensa dificuldade em conduzir a vida. Seu fim, seria o melhor acontecimento proporcionado pelo destino:

“ - aos trinta anos, eu ainda tinha esperança, em meio a grandes e avassaladoras depressões embora; aos cinqüenta, talvez já me encontre serenada, sem perceber o fora-de-meu-alcance. Aos quarenta, sinto-me completamente desorientada. Ainda me custa ceder, apesar de não ter mais por que lutar" (DMT, p.119).

A morte, como relata o onisciente narrador em terceira pessoa, era um fenômeno inacessível e desconhecido para Thereza, até o dia em que se vê diante do pai morto: "até a morte do pai, a morte não existia. Pelo menos em termos objetivos, não de corpo presente. Havia enterros, fumo, incenso, ausência. Mas não morte” (DMT, p.26). A revelação foi assombrosa e a jovem, pela primeira vez, deparou-se com a fragilidade da vida; "estarrecida ante a irrefutabilidade da morte, não lhe ocorreu nenhum pensamento que pudesse ser expresso em palavras. (...) O mundo, ele próprio, parecia haver sido violentado e ter sofrido um brusco movimento de retração" (DMT, p.26).

A morte do pai não causou somente sofrimentos psíquicos, mas fez com que Thereza e a mãe conhecessem a realidade cruel da existência física: a sensação de abandono, a dor terrivelmente física da perda e até mesmo a fome: "e a fome de bolo trouxe a Thereza a revelação de que no mundo havia fome" (DMT, p.26). 
Com a ausência do patriarca, a família anteriormente rica vai conhecer a pobreza, devido às muitas dívidas deixadas pelo falecido. Com o passar do tempo, mãe e filha são obrigadas a vender todos os seus pertences, inclusive o imenso e luxuoso casarão onde viviam, a fim de pagar aos agiotas. Depois de se desfazerem de todos os seus bens, elas são forçadas a mudar-se para uma fétida pensão e a mãe de Thereza, para obter o sustento, passa a costurar ininterruptamente: "a máquina de costura começou a fazer o mundo trepidar em surdina, ao mordiscar panos de variados matizes, amortalhando palavras e queixumes" (DMT, p.27).

Ao defrontar-se com a morte do pai e suas consequências, Thereza não conhece não só a dor da perda de um ente querido e de uma vida confortável como passou a experimentar sentimentos até então desconhecidos, como a angústia e outras muitas inquietações. Em cada parágrafo do romance, percebe-se a obsessão da personagem pela morte que é a configuração mais certa e misteriosa da existência humana, por mais misteriosa que fosse. Aliás, Thereza parecia não ter muito a perder, já que, com a morte do pai e em seguida a da mãe, ficara sem qualquer laço afetivo, uma vez que não possuía nenhum outro parente com quem pudesse se relacionar. Também não possuía bens materiais, nada que lhe proporcionasse segurança na vida. Isso contribuía para que desejasse precocemente o próprio fim, tendo em mente que "vida longa não é, necessariamente, uma vida de muitos anos vividos" (DMT, p.10). Então, por que permanecer viva?

De todas as personagens criadas por Elisa Lispector, Thereza é a que tem os mais negativos pensamentos sobre a existência. Contemplar a natureza era uma atitude que a entediava, uma vez que tudo lhe era insignificante:

"mas há a vida", insistiu, "bem pouca coisa, em verdade, o raiar da aurora, o brotar de uma flor, o canto de um pássaro, o grito sonoro de uma criança, a quietude, e a própria melancolia. E isto é a vida." E quando estivesse morta, e sepultada, não mais presenciaria isto. Não mais se rejubilaria, nem se entristeceria (DMT, p.17).

Para a personagem, o que havia de "transcendental na vida era a morte, já encarando a própria vida como uma ponte a conduzir à morte" (DMT, p.20). Assim, em face de tantos sofrimentos e percalços cotidianos, Thereza enxerga a sua finitude como um possível princípio. A sua vida escoa num lento e ritmado pulsar que, fatalmente, tem seu fim com a morte, e "assim, procurando morrer a sua morte, ela a vivia momento a momento" (DMT, p.18). 
De 1975 é o romance A última porta, que narra a história de Ana. Das personagens citadas, Ana é a mais velha de Elisa Lispector. Aos cinquenta anos, reflete de forma obsessiva a "própria dificuldade de ser, evidenciando-lhe, de súbito, toda a extensão de seu fracasso existencial” (UP, p.28). O narrador descreve a extensão de seu abandono e como vivia de forma embaraçada nas linhas rígidas da solidão.

Ana jamais experimentou a ternura de gestos e atitudes de carinho e afeto, sua vida sempre foi marcada pela rejeição. Quando criança, seus pais adotivos nunca lhe manifestaram amor ou qualquer outro sentimento afável. Na juventude, ao unir-se a Gastão - um homem rude e inclemente - também não encontra o aconchego de um amor sincero, pelo contrário, seu casamento foi marcado pela violência física e emocional do marido alcoólatra.

Sentindo-se sozinha, pois o marido, além do amor conjugal negava-lhe companhia, Ana resolve adotar um filho - assim que se convenceu da sua impossibilidade de engravidar. Como Marta - protagonista de Muro de Pedras - imaginava ser a maternidade, ainda que lograda pela natureza, um meio de encontrar a felicidade tão almejada e a segurança de possuir um relacionamento afetivo. Ou até mesmo uma maneira eficaz de preencher algumas das muitas lacunas de sua vida insípida e inútil. Porém, com o passar dos anos, a personagem depara-se com o fracasso na maternidade, pois não havia reciprocidade em seu relacionamento com o filho. Somente Ana amava, somente ela se doava ao filho Marcelo que não respondia a nenhum de seus carinhos e cuidados.

Mais uma indiferença que causava dano à alma da protagonista. $\mathrm{O}$ desamor do menino em relação à mãe aumentava com o seu crescimento, até que um dia este resolveu sair de casa, deixando a pobre mulher no mais doloroso abandono. Novamente Ana vê a existência lhe fechar mais uma porta - justamente a porta (isto é, a maternidade) que mais acreditou que pudesse levá-la ao encontro da felicidade de viver e ser útil nesse mundo.

Não só a protagonista em questão, mas a maioria das personagens criadas por Elisa Lispector busca superar a insegurança da e na solidão ancorando-se em relacionamentos líquidos, como afirmou Zygmunt Bauman, Amor líquido (2004). Houve uma busca no casamento e, depois, na maternidade uma ilusão de vínculos afetivos solidificados, mas que estes acabaram sucumbindo ao fracasso, conduzindo Ana mais uma vez à solidão.

Percorrendo suas lembranças, Ana convive com a agonia existencial, resultado das lutas perdidas. Disso percebe quão frágil é o seu viver e, que a vida era mais assustadora que a morte: 
Há muito, já, e particularmente nos últimos dias, vinha vivendo sob a sensação da fragilidade do ser, da vida pendendo por um fio. Tinha (...) a impressão de estar-se avizinhando de uma catástrofe. (...) Ana respirava dificilmente, sentindo o coração bater descompassado e o medo, como se, muito mais que a morte, temesse a vida (UP, p.17).

Ao recuar no tempo, esta mulher procurava sempre um ponto de referência a partir do qual pudesse reencontrar-se, porém, para onde quer que se voltasse, ia ter com as arestas agudas de um passado que a feriu e continuava ferindo. Em todas as suas tentativas de aproximação de um outro ser, encontrava barreiras que a impediam de se relacionar intimamente com o próximo e isso a incomodava. Mas como transpor tais obstáculos? Um meio encontrado pela personagem para atenuar tal fatalidade, a superficialidade de relacionamentos, foi voltar-se contra si mesma com inúmeros questionamentos.

Com inúmeras indagações sobre si mesma, Ana reflete sobre a sua miserável vida, na tentativa de encontrar alguma explicação para tanta frustração e, quem sabe, entender como chegou à condição extrema de desamor: "preciso falar, porque o silêncio não esvaziado da carga que as palavras contêm em si, em vez de aplacar o sofrimento, me estrangularia. Falando, sei que me exponho. No entanto, apego-me às palavras porque ainda constituem o meu único sustentáculo" (UP, p.111).

Romance de 1983, Corpo a corpo difere das outras narrativas por ter sido escrita em primeira pessoa. A protagonista cujo nome não é revelado, após a morte do marido, resolve refugiar-se no litoral na ânsia de rememorar a sua vida passada, em especial o período de seu casamento. A personagem-narradora abriga-se numa cabana e passa a repetir hábitos como caminhar com frequência à beira do mar, observar pacientemente o nascer do sol e o voo simples de uma gaivota, ir à aldeia próxima em busca de alimentos. Tomada por uma intensa nostalgia, a mulher escreve um diário. Se expõem por meio da linguagem um discurso que mescla a objetividade do relato à dicção de uma espécie de monólogo que denota a subjetividade de um "eu” torturado pela dor da separação e que vivencia um luto radical.

A mulher por trás desse "eu" narra a sua própria história ancorando-se no monólogo lírico. Contudo, há momentos em que o monólogo evidencia um lamento dirigido a uma "presença fantasmática" a quem ela lança perguntas e formula suas dúvidas, afirmando-se como um ser dividido. Fica claro desde o início da história que se trata de um ser em conflito consigo mesmo, na tentativa de reaver a sua identidade ao revisitar dias pretéritos. 
O objetivo da personagem é, então, rememorar os anos passados, especialmente, com a intenção sobretudo de perscrutar mais o não-vivido do que propriamente entender a vida vivida. Na tentativa de juntar os cacos dos tempos idos, reflete sobre a desastrosa relação de amor mantida com o marido recém-falecido, descobrindo que apenas a conivência tácita os mantivera juntos, pois já não existia entre eles diálogo, amizade ou carinho.

A partir de certas constatações advindas do modo labiríntico de escrever, a narradorapersonagem experimenta a dor e a angústia. Dilacerada pelas lembranças, ela é levada à autodegradação, à ferrenha autocrítica e ao autoflagelamento. Não obstante à ruína imposta pelas reminiscências, essa protagonista busca, de certa forma, reconstruir-se ao longo da narrativa, levada pelo fluxo da maré verbal.

O fio condutor da narrativa é a consciência da personagem que acena para possíveis saídas desse labirinto arquitetado pela memória. A história é apresentada por ela, narradorapersonagem, sendo a mesma ponte entre o passado e o presente e entre as outras raras personagens referidas no enredo - basicamente o marido e uma cunhada, esta mencionada poucas vezes. Trata-se de uma protagonista intrigante, dotada de uma admirável capacidade de expor seus sentimentos para se reconstruir. Corpo a corpo se encaixa como nos aspectos contemporâneos da narrativa cujo enredo não está voltado para a representação do choque do indivíduo com a ordem social, mas localiza basicamente nas contradições da vida interior das personagens.

Elisa Lispector engendra uma ficção introspectiva, que trafega por caminhos subjetivos, preocupando-se mais com descrições e referentes internos do que ocorrências factuais. Não que estejam ausentes de sua narrativa os elementos que refletem aspectos sociais. Estes podem ser encontrados, por exemplo, quando é mencionada a condição aparentemente subalterna da mulher em face da ordem paternalista, representada pelo marido insensível que, por meio de ações hostis e dominadoras, encurrala a personagem trancafiando-a (como ela mesma afirma) em um cerco (quase) intransponível.

De modo geral, suas protagonistas apresentam-se como seres mergulhados em uma profunda tristeza. O estado emocional de cada personagem é observável a partir dos seus discursos marcados por um desmedido pessimismo diante da própria existência, ora latente ora muito evidente. Para esses indivíduos não há mais razão de permanecer existindo. Daí a ânsia pelo isolamento e morte como afirma a protagonista de Corpo a corpo: "tive a necessidade de isolar-me para meditar e fazer um acerto de contas comigo mesma. Algo fiquei me devendo, e 
enquanto não se fizesse luz na confusão dos meus sentimentos, enquanto não compreendesse o que aconteceu, como e por que assim aconteceu, eu não teria paz (CAC, p.10).

\section{O fim de um percurso labiríntico}

A simbologia do labirinto pode ser evocada pelas tentativas de movimento de cada personagem rumo a busca de solução de suas agonias. Por meio de cada gesto, vemos a narrativa ganhar corpo por meio de uma construção sinuosa, cheia de meandros e complexidades. A desordem lógica aos temas evocados por Elisa Lispector ganha composição por meio do trabalho da linguagem, destacando os sentimentos de solidão, de isolamento e de morte. Não deixando de evidenciar que os contornos usados em cada tema são singulares na composição de cada personagem, demonstrando a originalidade dos conflitos.

Em Muro de pedras, Marta, mesmo imersa no mais profundo desespero, luta para adquirir um sentido para sua existência: busca na maternidade uma saída para sentir-se livre da sensação de inutilidade. Por outro lado, as personagens Sérgio (de Além da fronteira) e Thereza (de $O$ dia mais longo de Thereza) veem na morte, não na vida, uma solução para os seus sofrimentos. Todavia, Sérgio e Thereza possuem olhares diferentes em relação a esse iniludível fenômeno, que é a morte. O primeiro, no fundo, o teme e questiona, enquanto Thereza, presa na autocomiseração, entrega-se cada vez mais à morte, a ponto de intentar contra a própria existência.

No mais, o propósito desta apresentação da obra elisiana não é pontuar as semelhanças e diferenças entre as personagens. É, sobretudo, revelar ao leitor as múltiplas maneiras encontradas pela autora de repetir algumas temáticas, salientando a riqueza interior de cada personagem. Procuramos chamar a atenção para o labor poético existente em cada narrativa, o qual sustenta a incursão por diversas temáticas, mas permanecendo fiel às reflexões impostas pelos fenômenos poéticos nascido das narrativas, como a agonia existencial em face da vida e da morte, a solidão, a transitoriedade do tempo, a incomunicabilidade diante de sofrimentos aterradores.

Nesse vislumbre panorâmico da obra de Elisa Lispector, destacamos um ritmado questionamento acerca da finitude existencial, em que os caminhos percorridos devem ser revitalizados a cada passo. A obra elisiana retoma com vigor a reflexão rosiana, nos dizeres da protagonista de Corpo a corpo: “- viver é inquietante, e tão perigoso que é preciso respirar 
devagar para não morrer de susto" (CAC, p. 21. Grifo nosso), o qual revela um medo individual e coletivo do homem diante desse mundo desordenado e caótico em que vivemos e que não é fácil escapar ileso, sem traumas. Para as personagens a escrita se transforma em fio condutor, mas não se alcança a saída com tanta maestria como os heróis mitológicos.

Percebemos que a autora arquitetou um grande diálogo envolvendo toda a sua produção literária. Ou melhor, é como se suas personagens vivessem intensamente para estabelecer com o mundo e com os homens um diálogo criador. Daí muitas semelhanças em seus livros semelhanças tanto na forma como no conteúdo. Parece-nos que as protagonistas elisianas, a uma só voz, querem expor os pensamentos atormentados - suas angústias, suas injustiças, suas vidas decadentes, seus medos e pesadelos por meio da prosa poética.

Enfim, permeando o conjunto da produção literária de Elisa Lispector estão presentes relevantes questionamentos sobre a existência humana, aproximando-se a literatura da forma reflexiva da filosofia.

\section{Referências}

ARRIGUCCI JÚNIOR, Davi. Humildade, paixão e morte: a poesia de Manuel Bandeira. São Paulo: Companhia das Letras, 1990.

AYALA, Walmir. Apresentação. In: LISPECTOR, Elisa. Muro de pedras.

BAUMAN, Zygmunt. Amor líquido. Tradução Carlos Alberto Medeiros. Rio de Janeiro: Jorge Zahar, 2004.

BRANDÃO, Junito de Souza. Mitologia Grega. 18.ed. Petrópolis: Vozes, 2004. v. I. . Mitologia Grega. 15. ed. Petrópolis: Vozes, 2005. v. II. . Mitologia Grega. 12. ed. Petrópolis: Vozes, 2002. v. III.

FUKELMAN, Clarisse. "Escreve estrelas (ora, direis)". In: A hora da estrela. Rio de Janeiro: Record,1977. p.7-25.

GOLTLIB, Nádia Battela. Clarice uma vida que se conta. São Paulo: Editora da Universidade de São Paulo, 2009.

JOSEF, Bella. Prefácio. In: LISPECTOR, Elisa. Tigre de Bengala. Rio de Janeiro: José Olympio, 1985.

LISPECTOR, Elisa. Inventário. (contos) Rio de Janeiro: Rocco, 1997. . Além da fronteira. (romance) Rio de Janeiro: José Olympio, 1988. . O tigre de Bengala. (contos) Rio de Janeiro: José Olympio, 1985. 
. Corpo a corpo. (romance) Rio de Janeiro: Edições Antares, 1983.

. O dia mais longo de Thereza. (romance) Rio de Janeiro: Record, 1978.

. A última porta. (romance) Rio de Janeiro: Documentário, 1975.

. No exílio. (romance) 2.ed. Brasília: Editora de Brasília - EBRASA, 1971.

. Sangue no sol. (contos) Brasília: Editora de Brasília - EBRASA, 1970.

. Muro de pedras. (romance) Rio de Janeiro: José Olympio, 1963.

MARTINS, Gilberto Figueiredo. Alter(c)idades - um exercícios de escalas. (Espaço público, modos de subjetivação e formas de sociabilidade na obra de Clarice Lispector). 2002. Tese de Doutorado. Departamento de Letras Clássicas e Vernáculas, Universidade de São Paulo, São Paulo, 2002.

WALDMAN, Berta. Entre rastros e passos: presença judaica na literatura brasileira contemporânea. São Paulo: Perspectiva: FAPESP: Associação Universitária de Cultura Judaica, 2003.

Artigo recebido em: 17.10.2019

Artigo aceito para publicar em: 26.11.2019 